Article

\title{
Preparation of Silicophosphate Alternating Hybrid Copolymers via Nonaqueous Acid-Base Reactions of Phosphoric Acid and Organo-Bridged Bis(chlorosilane)
}

\author{
Kenji Okada ${ }^{1,2, *(\mathbb{D}, \text { Masanari Takano }}{ }^{1}$, Yasuaki Tokudome ${ }^{1}$, Yomei Tokuda ${ }^{3}$ and \\ Masahide Takahashi ${ }^{1, *(D)}$ \\ 1 Department of Materials Science, Graduate School of Engineering, Osaka Prefecture University, Sakai, \\ Osaka 599-8531, Japan; takanom@photomater.com (M.T.); tokudome@mtr.osakafu-u.ac.jp (Y.T.) \\ 2 JST, PRESTO, 4-1-8 Honcho, Kawaguchi, Saitama 332-0012, Japan \\ 3 Faculty of Education, Shiga University, Otsu, Shiga 520-0862, Japan; tokuda@edu.shiga-u.ac.jp \\ * Correspondence: okada@photomater.com (K.O.); masa@photomater.com (M.T.)
}

Academic Editor: Masafumi Unno

Received: 28 November 2019; Accepted: 26 December 2019; Published: 28 December 2019

\begin{abstract}
A design of atomic and oligomer level structure in organic-inorganic hybrid materials is highly important for various applications. Nonaqueous acid-base reaction allows us to prepare silicophosphates with controlled inorganic networks $\left(-(\mathrm{O}-\mathrm{P}-\mathrm{O}-\mathrm{Si})_{\mathrm{n}}\right)$ at atomic level because phosphorous and silicon-based precursors can react directly, resulting in an alternating copolymer network. Organic functionalization in those materials has been realized so far by using organic-modified phosphorous acid and/or organo-chlorosilane as precursors. In the present study, silicophosphate oligomers exhibiting inorganic-organic hybrid chains of $\left(-(\mathrm{O}-\mathrm{P}-\mathrm{O}-\mathrm{Si}-\mathrm{R}-\mathrm{Si})_{\mathrm{n}}\right)$ (R: bridging organic functional groups), are prepared from phosphoric acid and organo-bridged bis(chlorosilane). The 1, 2-bis(chlorodimethylsilyl)ethane $\left(\left(\mathrm{C}_{2} \mathrm{H}_{4}\right)\left(\mathrm{Me}_{2} \mathrm{SiCl}\right)_{2}\right)$ and 1, 4-bis(chlorodimethylsilyl)benzene $\left(\left(\mathrm{C}_{6} \mathrm{H}_{4}\right)\left(\mathrm{Me}_{2} \mathrm{SiCl}_{2}\right)\right.$ were used as organo-bridged bis(chlorosilane). Different types of silicophosphate oligomers with different network structures and terminal groups ( $\mathrm{P}-\mathrm{OH}$ and/or $\mathrm{Si}-\mathrm{Cl}$ ) were prepared by changing the reaction temperature and molar ratio of precursors. The formation of low molecular weight oligomers of ring and cage morphologies (ring tetramer, cage pentamer, and ring hexamer) is suggested in the product prepared from phosphoric acid and $\left(\mathrm{C}_{6} \mathrm{H}_{4}\right)\left(\mathrm{Me}_{2} \mathrm{SiCl}\right)_{2}$ molecule at $150^{\circ} \mathrm{C}$. Those silicophosphate hybrid oligomers are expected to be used as building blocks of hybrid materials with well-defined network structures for desired functionalities.
\end{abstract}

Keywords: silicophosphate; nonaqueous acid-base reaction; organo-bridged silane; organic-inorganic hybrid material; cage molecule; phosphoric acid; density functional theory; alternating copolymer.

\section{Introduction}

Organic-inorganic hybrid materials have attracted attention because of the unique properties derived from both organic and inorganic moieties. As one of the famous hybrid materials, polydimethylsiloxane (PDMS) is widely used for applications ranging from medical applications to optical devices due to its optical transparency, non-toxicity, non-flammability, and mechanical flexibility. The properties of the hybrid materials are mostly determined by the chemistry of the organic and inorganic components, their arrangements, and the microstructures [1,2]. These hybrid materials are widely synthesized via an alkoxide-derived sol-gel method because the low temperature process prevents the decomposition of the organic component [3-5]. However, the conformation of the organic 
and inorganic components is hardly controllable by the alkoxide-derived sol-gel method because the hydrolysis and condensation reactions of inorganic moieties of organically modified alkoxides take place competitively, which results in different nucleation-growth processes. A solvent-free sol-gel method which involves the nonhydrolytic condensation and nonaqueous acid-base reaction allowed us to prepare highly controlled inorganic networks at an atomic level because precursors can react directly with the counterpart [6-8]. We have reported silicate-phosphate (silicophosphate) and silicate-phosphite (silico-phosphite) alternating copolymers $\left(-(\mathrm{O}-\mathrm{P}-\mathrm{O}-\mathrm{Si})_{\mathrm{n}}\right)$ by a direct reaction of phosphoric acid (or phosphorous acid) and organically modified chlorosilane [9-12]. The network formation process involved a nonaqueous acid-base reaction as follows: $\mathrm{P}-\mathrm{OH}+\mathrm{Si}-\mathrm{Cl} \rightarrow \mathrm{P}-\mathrm{O}-\mathrm{Si}$ $+\mathrm{HCl} \uparrow$. Thus, the phosphorous and silicon precursors are alternatingly linked by oxo bridges. The resultant hybrid materials exhibited low glass transition temperatures around at $-25^{\circ} \mathrm{C}$ to $70{ }^{\circ} \mathrm{C}$, which allowed for the homogeneous introduction of optically active organic dyes and rare-earth ions in the hybrid materials for optical applications [13]. It was found that the molecular structures and the oligomer-scale networks were related to the chemical durability and the thermal properties of the hybrid materials $[14,15]$. Silicophosphate oxo bridges (Si-O-P) were quite hygroscopic due to the hydrolysis by water in ambient atmosphere. Usually, size and hydrophobicity of the organic group largely affect the stability. It has been reported that the phenyl-modified silicophosphate materials with $100 \%$ degree of condensation exhibit good stability in an ambient atmosphere. This was achieved by introducing bulky and hydrophobic moiety like phenyl group and also by the highly linked well-developed oxo networks [14]. On the other hand, it is well known that the network dimension and degree of condensation largely affect the thermal property of the resultant polymeric materials, especially for the softening temperature. Actually, it is expected for the organically modified silicophosphate materials as one of alternatives of so-called "low-melting glasses" which have softening (glass transition) temperature around $100^{\circ} \mathrm{C}-400^{\circ} \mathrm{C}$. We have also reported that the silicophosphate materials are one of the candidates for such alternative materials $[15,16]$. Thus, the design of these structures is important to control the chemical, thermal, and optical properties.

In the present study, silicophosphate hybrid oligomers, which contain organic moieties in inorganic main chains, were prepared from phosphoric acid and organo-bridged bis(chlorosilane) by nonaqueous acid-base reactions. The 1,2-bis(chlorodimethylsilyl)ethane $\left(\left(\mathrm{C}_{2} \mathrm{H}_{4}\right)\left(\mathrm{Me}_{2} \mathrm{SiCl}\right)_{2}\right)$ and 1,4-bis(chlorodimethylsilyl)benzene $\left(\left(\mathrm{C}_{6} \mathrm{H}_{4}\right)\left(\mathrm{Me}_{2} \mathrm{SiCl}\right)_{2}\right)$ were used as organo-bridged bis(chlorosilane). In the silicophosphates reported so far, organic functional groups were introduced as the side chain of the $\left(-(\mathrm{O}-\mathrm{P}-\mathrm{O}-\mathrm{Si})_{\mathrm{n}}\right)$ networks. The use of organo-bridged bis(chlorosilane) as precursors resulted in the incorporation of organic moieties in the inorganic networks as $\left(-(\mathrm{O}-\mathrm{P}-\mathrm{O}-\mathrm{Si}-\mathrm{R}-\mathrm{Si})_{\mathrm{n}}\right)(\mathrm{R}$ : Bridging organic functional groups), which attain the further flexibility for a design of atomic level structures in the hybrid materials. In addition, the formation of regular structures, such as layered structures and cage structures, is expected in the hybrid materials as reported in the conventional sol-gel derived organo-silica, metal organic framework, and metal-organic polyhedra, which provide us sophisticated properties, such as gas sorption, and unique optical and mechanical properties [17-21]. Herein, different types of silicophosphate oligomers were prepared from phosphoric acid and organo-bridged bis(chlorosilane) by simply changing the reaction temperature and molar ratio of precursors. The structures of silicophosphate oligomers were investigated by nuclear magnetic resonance (NMR) and gel permeation chromatography (GPC). The silicophosphate oligomers are expected to be used as building blocks for preparing hybrid materials with well-defined molecular structures for desired functionalities.

\section{Results and Discussion}

\subsection{Reactivity between Phosphoric Acid and Organo-Bridged Bis(Chlorosilane) and the Preparation of Silicophosphate Oligomers}

The silicophosphate hybrid oligomers were synthesized by a nonaqueous acid-base reaction between phosphoric acid and organo-bridged bis(chlorosilane) $\left(\left(\mathrm{C}_{2} \mathrm{H}_{4}\right)\left(\mathrm{Me}_{2} \mathrm{SiCl}\right)_{2}\right.$ or $\left.\left(\mathrm{C}_{6} \mathrm{H}_{4}\right)\left(\mathrm{Me}_{2} \mathrm{SiCl}\right)_{2}\right)$ (Figure 1). In this method, the precursors were mixed under $\mathrm{N}_{2}$ atmosphere and then gradually 
heated to predetermined temperatures. Then, the solutions were kept at the temperature for $5.5 \mathrm{~h}$ and cooled to an ambient temperature. In the nonaqueous conditions, $\mathrm{H}_{2} \mathrm{PO}_{4}{ }^{-}$anions were produced by autoprotolysis of phosphoric acid. The $\mathrm{H}_{2} \mathrm{PO}_{4}{ }^{-}$anion as nucleophilic reagent attached to silicon in organo-bridged bis(chlorosilane) by $\mathrm{S}_{\mathrm{N}} 2(\mathrm{Si})$ addition reaction, resulting in the formation of $\mathrm{P}-\mathrm{O}-\mathrm{Si}$ linkage. According to the reaction mechanism, the energy gap between HOMO energy level of $\mathrm{H}_{2} \mathrm{PO}_{4}{ }^{-}$anion and LUMO energy level of organo-bridged bis(chlorosilane) determined the reactivity between phosphorus and silicon precursors and the yield of the resultant hybrid materials ${ }^{12}$. Figure $1 \mathrm{~b}$ shows the HOMO and LUMO energy levels of the precursors. The HOMO level of the $\mathrm{H}_{2} \mathrm{PO}_{4}{ }^{-}$ anion was contributed by the O-2p orbital. LUMO levels of the organo-bridged bis(chlorosilane) were constructed mainly by the Si-4p orbital. The LUMO levels with the same energy were confirmed in the $\left(\mathrm{C}_{2} \mathrm{H}_{4}\right)\left(\mathrm{Me}_{2} \mathrm{SiCl}\right)_{2}$ and $\left(\mathrm{C}_{6} \mathrm{H}_{4}\right)\left(\mathrm{Me}_{2} \mathrm{SiCl}\right)_{2}$ precursors, indicating that the both silicon precursors exhibited the same reactivity to phosphoric acid.

(a)

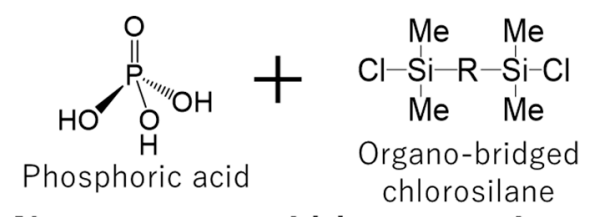

Nonaqueous acid-base reaction
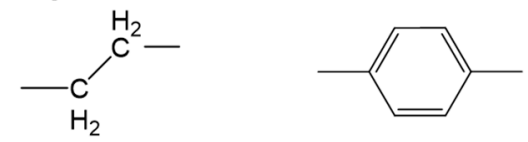

$\mathrm{R}=\mathrm{C}_{2} \mathrm{H}_{4}$

$\mathrm{R}=\mathrm{C}_{6} \mathrm{H}_{4}$

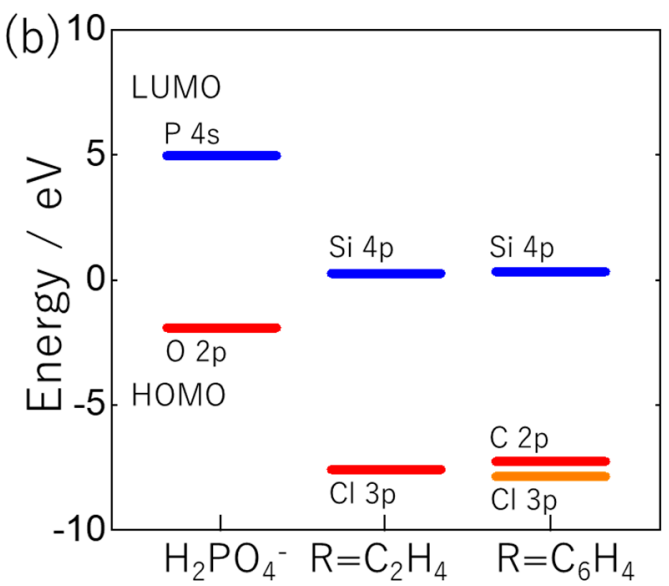

Figure 1. (a) Precursors used in the present study, (b) HOMO and LUMO energy levels of $\mathrm{H}_{2} \mathrm{PO}_{4}{ }^{-}$, $\left(\mathrm{C}_{2} \mathrm{H}_{4}\right)\left(\mathrm{Me}_{2} \mathrm{SiCl}\right)_{2}$ and $\left(\mathrm{C}_{6} \mathrm{H}_{4}\right)\left(\mathrm{Me}_{2} \mathrm{SiCl}\right)_{2}$ molecules evaluated by DFT calculation.

\subsection{Silicophosphate Hybrid Network Formation from Phosphoric Acid and $\left(\mathrm{C}_{2} \mathrm{H}_{4}\right)\left(\mathrm{Me}_{2} \mathrm{SiCl}\right)_{2}$}

The phosphoric acid and $\left(\mathrm{C}_{2} \mathrm{H}_{4}\right)\left(\mathrm{Me}_{2} \mathrm{SiCl}\right)_{2}$ were mixed with a stoichiometric composition $\left(\mathrm{H}_{3} \mathrm{PO}_{4}\right.$ : $\left.\left(\mathrm{C}_{2} \mathrm{H}_{4}\right)\left(\mathrm{Me}_{2} \mathrm{SiCl}\right)_{2}=1: 1.5\right)$ and reacted in THF at 50,100, and $150^{\circ} \mathrm{C}$. Spinnable and transparent products were obtained. Figure 2 shows ${ }^{31} \mathrm{P}$ and ${ }^{29} \mathrm{Si}$ NMR spectra of the products prepared at 50 and $100{ }^{\circ} \mathrm{C}$. In the ${ }^{31} \mathrm{P}$ NMR spectra, three distinct peaks were observed at $-4.8,-12.8$, and $-22.5 \mathrm{ppm}$, which were assigned to $\mathrm{Q}^{1}, \mathrm{Q}^{2}$, and $\mathrm{Q}^{3}$ units, respectively. The fraction of each unit was calculated from the NMR spectra. The higher reaction temperature of $100{ }^{\circ} \mathrm{C}$ led to a decrease of the fraction of $\mathrm{Q}^{2}$ unit from $66.5 \%$ for $50{ }^{\circ} \mathrm{C}$ to $46.5 \%$ for $100{ }^{\circ} \mathrm{C}$ and an increase of that of $\mathrm{Q}^{3}$ unit from $29.2 \%$ to $50.0 \%$ with maintaining that of $\mathrm{Q}^{1}$ unit $\left(4.3 \%\right.$ for $50^{\circ} \mathrm{C}$ and $3.5 \%$ for $\left.100^{\circ} \mathrm{C}\right)$. This result indicates that both products contained $\mathrm{P}-\mathrm{OH}$ at the terminal of the $\left(-\left(\mathrm{O}-\mathrm{P}-\mathrm{O}-\mathrm{Si}-\mathrm{C}_{2} \mathrm{H}_{4}-\mathrm{Si}\right)_{n}\right)$ networks and the products prepared at $100{ }^{\circ} \mathrm{C}$ had more branched networks. In the ${ }^{29} \mathrm{Si}$ NMR spectra, two distinct peaks were observed at 33.1 and $21.6 \mathrm{ppm}$, which were assigned to $\mathrm{M}^{0}$ and $\mathrm{M}^{1}$ units. The fractions of $\mathrm{M}^{0}$ and $\mathrm{M}^{1}$ units for the 
product prepared at $50{ }^{\circ} \mathrm{C}$ were calculated as $14.8 \%$ and $85.2 \%$. In the product prepared at $100{ }^{\circ} \mathrm{C}$, $\mathrm{M}^{1}$ unit was the dominant structural unit as the fractions of $\mathrm{M}^{0}$ and $\mathrm{M}^{1}$ units were $0.05 \%$ and $99.5 \%$, respectively. A similar result was observed for that at $150{ }^{\circ} \mathrm{C}$ (Figure S1). GPC investigation indicated that the resultant products were constituted of lower molecular weight molecules than $1000 \mathrm{~g} / \mathrm{mol}$, which was calculated according to the molecular weight of standard polystyrene. From these results, it was concluded that the product prepared at $50{ }^{\circ} \mathrm{C}$ contained both $\mathrm{P}-\mathrm{OH}$ and $\mathrm{Si}-\mathrm{Cl}$ at the terminal of the networks, while the terminal of the networks at $100^{\circ} \mathrm{C}$ and $150{ }^{\circ} \mathrm{C}$ was mostly P-OH. The formation of linear and/or cyclic oligomers was assumed in the product prepared at $50^{\circ} \mathrm{C}$ by comparing with those at $100{ }^{\circ} \mathrm{C}$ and $150^{\circ} \mathrm{C}$ because the linear $\mathrm{Q}^{2}$ unit is the main structural unit. Cyclic oligomers and polyhedral (e.g., cage and double-decker) likely form in the products prepared at $100{ }^{\circ} \mathrm{C}$ and $150{ }^{\circ} \mathrm{C}$ because the branched $\mathrm{Q}^{3}$ unit was the main structural unit and the fraction of $\mathrm{Q}^{1}$ unit was relatively low compared to that of the $\mathrm{Q}^{3}$ unit.
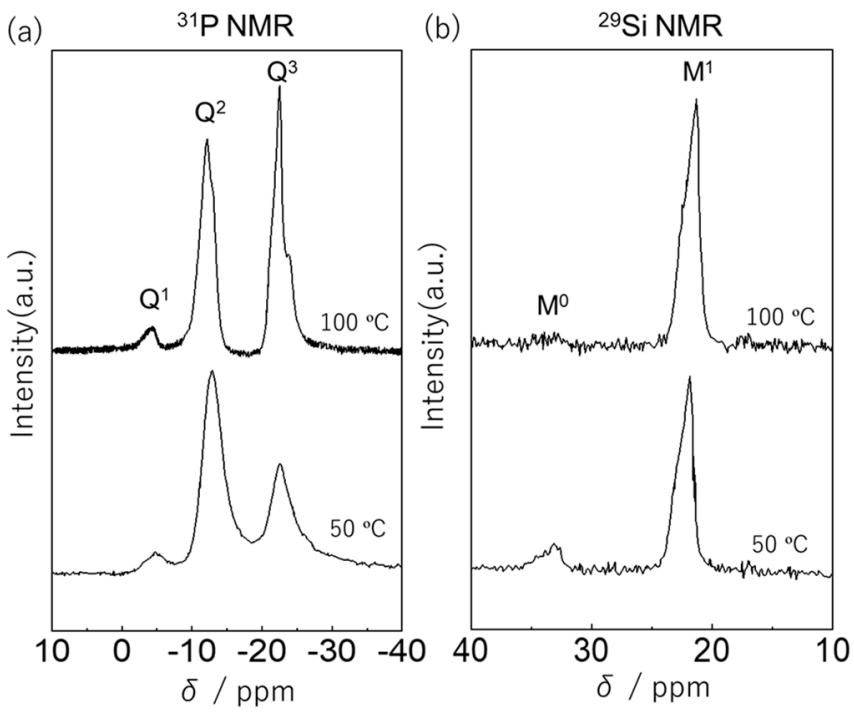

Figure 2. (a) The ${ }^{31} \mathrm{P}$ and (b) ${ }^{29} \mathrm{Si}$ NMR spectra of the products prepared from phosphoric acid and $\left(\mathrm{C}_{2} \mathrm{H}_{4}\right)\left(\mathrm{Me}_{2} \mathrm{SiCl}\right)_{2}$ at $50{ }^{\circ} \mathrm{C}$ and $100{ }^{\circ} \mathrm{C}$.

\subsection{Silicophosphate Hybrid Network Formation from Phosphoric Acid and $\left(\mathrm{C}_{6} \mathrm{H}_{4}\right)\left(\mathrm{Me}_{2} \mathrm{SiCl}\right)_{2}$}

Clear and viscous products with a bit brownish color were obtained by a reaction between phosphoric acid and $\left(\mathrm{C}_{6} \mathrm{H}_{4}\right)\left(\mathrm{Me}_{2} \mathrm{SiCl}\right)_{2}$ in THF with a stoichiometric composition $\left(\mathrm{H}_{3} \mathrm{PO}_{4}\right.$ : $\left.\left(\mathrm{C}_{6} \mathrm{H}_{4}\right)\left(\mathrm{Me}_{2} \mathrm{SiCl}\right)_{2}=1: 1.5\right)$ at $25,50,100$, and $150{ }^{\circ} \mathrm{C}$. Figure $3 \mathrm{a}, \mathrm{b}$ shows ${ }^{31} \mathrm{P}$ and ${ }^{29} \mathrm{Si} \mathrm{NMR}$ spectra of the products prepared at each temperature. The peaks at $2.8,-5.1,-13.5$, and $-24.8 \mathrm{ppm}$ in the ${ }^{31} \mathrm{P}$ NMR spectra are assigned to $Q^{0}, Q^{1}, Q^{2}$, and $Q^{3}$ units, respectively. The peaks at 19.9 and $9.2 \mathrm{ppm}$ in the ${ }^{29} \mathrm{Si}$ NMR spectra are assigned to $\mathrm{M}^{0}$ and $\mathrm{M}^{1}$ units. Figure $3 \mathrm{c}$, d shows the fraction of each unit at different reaction temperatures. The phosphoric acid exhibited higher reactivity to $\left(\mathrm{C}_{6} \mathrm{H}_{4}\right)\left(\mathrm{Me}_{2} \mathrm{SiCl}\right)_{2}$ molecules at higher temperatures. The ${ }^{29} \mathrm{Si}$ NMR investigation showed that all chlorine in $\left(\mathrm{C}_{6} \mathrm{H}_{4}\right)\left(\mathrm{Me}_{2} \mathrm{SiCl}\right)_{2}$ molecules reacted with the phosphoric acid, resulting in the formation of P-O-Si linkage at the reaction temperature over $100{ }^{\circ} \mathrm{C}$. Notably, the formation of only $\mathrm{Q}^{2}$ and $\mathrm{Q}^{3}$ structural units was observed in the product prepared at $150{ }^{\circ} \mathrm{C}$, indicating that the product contained no terminal $\mathrm{P}-\mathrm{OH}$ and $\mathrm{Si}-\mathrm{Cl}$ in the networks and phosphoric acid, and $\left(\mathrm{C}_{6} \mathrm{H}_{4}\right)\left(\mathrm{Me}_{2} \mathrm{SiCl}\right)_{2}$ molecules were alternatingly connected to each other. Under this condition, the fractions of $\mathrm{Q}^{2}$ and $\mathrm{Q}^{3}$ units were $37.3 \%$ and $62.7 \%$, respectively. The result indicates the formation of cyclic oligomers as well as cage molecules at $150{ }^{\circ} \mathrm{C}$. 


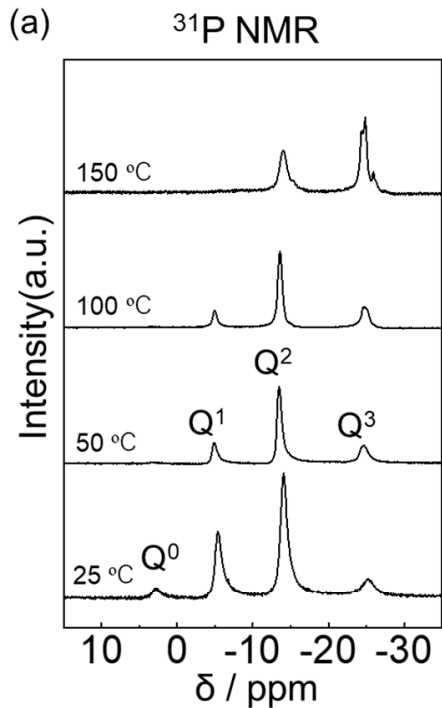

(b) $\quad{ }^{29} \mathrm{SiNMR}$
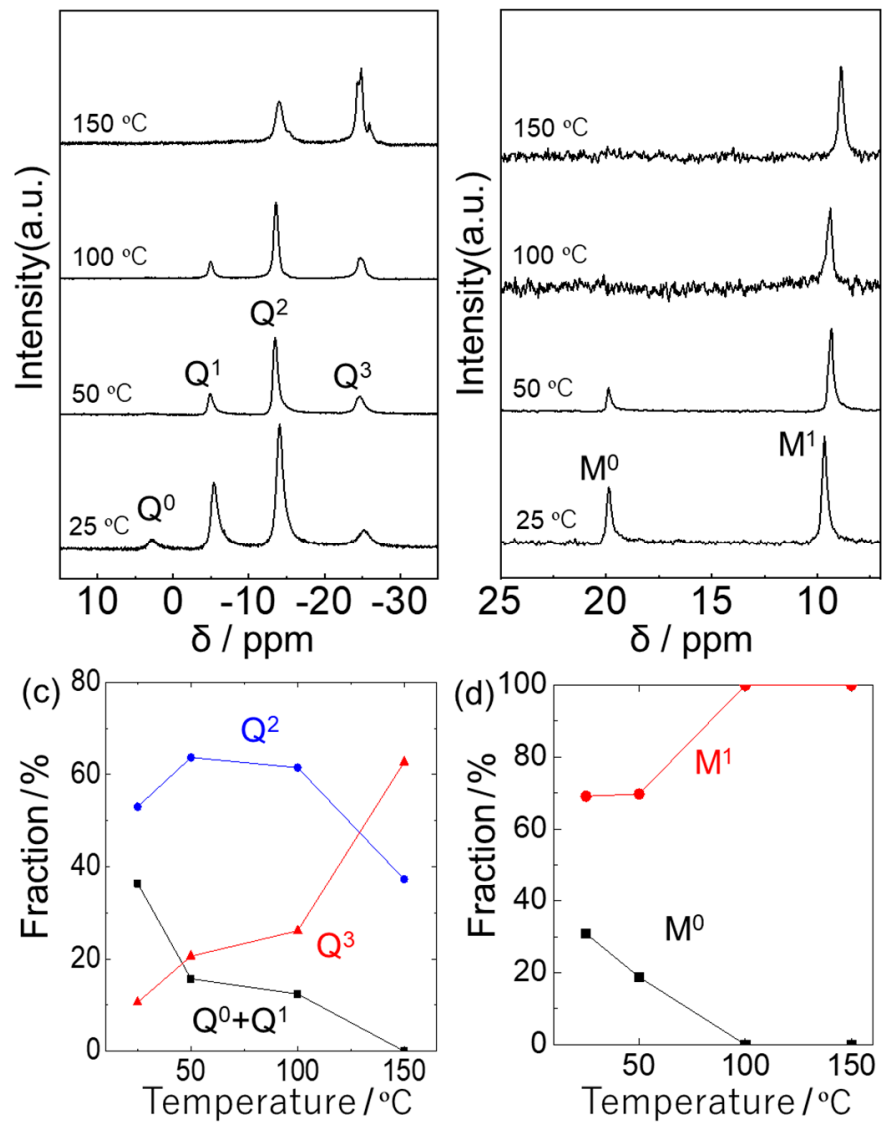

Figure 3. (a) The ${ }^{31} \mathrm{P}$ and (b) ${ }^{29} \mathrm{Si}$ NMR spectra of the products prepared from phosphoric acid and $\left(\mathrm{C}_{6} \mathrm{H}_{4}\right)\left(\mathrm{Me}_{2} \mathrm{SiCl}\right)_{2}$ at each temperature. (c) The fraction of $\mathrm{Q}^{0}, \mathrm{Q}^{1}, \mathrm{Q}^{2}$, and $\mathrm{Q}^{3}$ units at each temperature calculated from ${ }^{31} \mathrm{P}$ NMR spectra. (d) The fraction of $\mathrm{M}^{0}$ and $\mathrm{M}^{1}$ units at each temperature calculated from ${ }^{29} \mathrm{Si}$ NMR spectra.

The effect of composition, in terms of molar ratio, of $\mathrm{H}_{3} \mathrm{PO}_{4}:\left(\mathrm{C}_{6} \mathrm{H}_{4}\right)\left(\mathrm{Me}_{2} \mathrm{SiCl}\right)_{2}=1: \mathrm{x}(\mathrm{x}=0.5$, $1.0,1.5,1.68,2.0,2.5,3.0)$ was investigated at $150{ }^{\circ} \mathrm{C}$ reaction temperature. When the molar ratio of silicon precursor was less than stoichiometric composition $(x<1.5)$, viscous products, that were insoluble in tetrahydrofuran (THF), were obtained (therefore, NMR measurement was not conducted for these products). This is presumably because high-molecular weight silicophosphate is prepared by a self-condensation of phosphoric acid. Figure 4 shows ${ }^{31} \mathrm{P}$ NMR spectra and the corresponding fraction of the products prepared at different compositions $(x=1.5,1.68,2.0,2.5,3.0)$. An increase of $\mathrm{Q}^{3}$ unit and a split of the peak related to $\mathrm{Q}^{3}$ unit were observed with increasing the molar fraction of the $\left(\mathrm{C}_{6} \mathrm{H}_{4}\right)\left(\mathrm{Me}_{2} \mathrm{SiCl}\right)_{2}$. The peak splitting indicates the formation of $\mathrm{Q}^{3}$ unit in different chemical environments. At $x=3.0$, the network was composed of mostly branched $Q^{3}$ units linked by linear $\left(\mathrm{C}_{6} \mathrm{H}_{4}\right)\left(\mathrm{Me}_{2} \mathrm{SiCl}\right)_{2}$ molecules. In that product, the terminal group of the inorganic networks was determined as $\mathrm{Si}-\mathrm{Cl}$ because both $\mathrm{M}^{0}$ and $\mathrm{M}^{1}$ units were confirmed by ${ }^{29} \mathrm{Si} \mathrm{NMR}$ investigation (Figure S2). The products prepared at $\mathrm{x}=1.5$ and 3.0 were investigated by GPC (Figures S3-S6). The product of $x=1.5$ was constituted of only lower molecular weight molecules, like cyclic and cage molecules less than $1000 \mathrm{~g} / \mathrm{mol}$, which was calculated according to the standard polystyrene. On the other hand, the composition at $x=3.0$ resulted in the silicophosphate alternating copolymers with a wide range of molecular weight from 200 to $10,000 \mathrm{~g} / \mathrm{mol}$. 

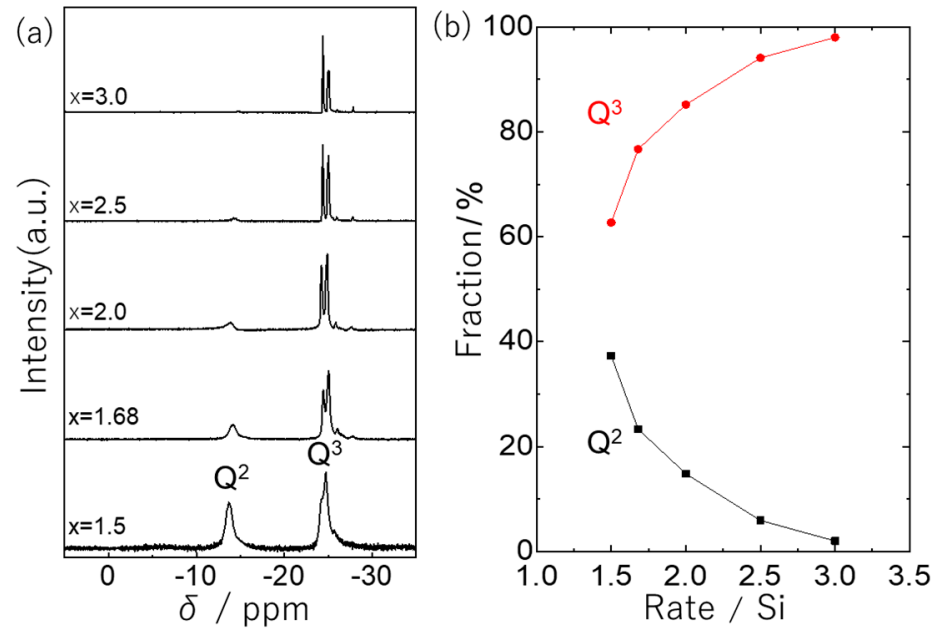

Figure 4. (a) The ${ }^{31} \mathrm{P}$ NMR spectra and (b) the corresponding fraction of $\mathrm{Q}^{2}$ and $\mathrm{Q}^{3}$ units at each composition calculated from ${ }^{31} \mathrm{P}$ NMR spectra in the $\mathrm{H}_{3} \mathrm{PO}_{4}-\left(\mathrm{C}_{6} \mathrm{H}_{4}\right)\left(\mathrm{Me}_{2} \mathrm{SiCl}\right)_{2}$ system.

In the present study, different types of silicophosphate oligomers with different network structures (such as cyclic and cage oligomers) and terminal groups ( $\mathrm{P}-\mathrm{OH}$ and/or $\mathrm{Si}-\mathrm{Cl}$ ) were prepared by changing the reaction temperature and molar ratio of the precursors. Although various types of molecular silicophosphates, such as cyclic and cage oligomers, have been reported so far [22-26], this is the first report on the synthesis of silicophosphates oligomers which contain organic moieties in inorganic main chains. The organic moieties incorporated in the inorganic chains of silicophosphates can increase the surface area as reported in silicophosphate xerogels prepared from bridged acetoxysilanes and phosphoryl reagents [27]. This advantage allows for the further use as building blocks for preparing hybrid materials with well-defined network structures for desired functionalities.

\section{Materials and Methods}

Orthophosphoric acid, $\mathrm{H}_{3} \mathrm{PO}_{4} \quad(\geq 99.999 \%$, Sigma-Aldrich Co., Tokyo, Japan), 1, 2-Bis(Chlorodimethylsilyl)ethane, $\left(\mathrm{C}_{2} \mathrm{H}_{4}\right)\left(\mathrm{Me}_{2} \mathrm{SiCl}\right)_{2} \quad(96 \%$, Sigma-Aldrich Co.), and 1 , 4-Bis(Chlorodimethylsilyl)benzene, $\left(\mathrm{C}_{6} \mathrm{H}_{4}\right)\left(\mathrm{Me}_{2} \mathrm{SiCl}\right)_{2}(95 \%$, Sigma-Aldrich Co.) were used as precursors. All the samples were prepared under a $\mathrm{N}_{2}$ atmosphere as reported [9]. For the $\mathrm{H}_{3} \mathrm{PO}_{4}-\left(\mathrm{C}_{2} \mathrm{H}_{4}\right)\left(\mathrm{Me}_{2} \mathrm{SiCl}\right)_{2}$ system, $\mathrm{H}_{3} \mathrm{PO}_{4}$ and $\left(\mathrm{C}_{2} \mathrm{H}_{4}\right)\left(\mathrm{Me}_{2} \mathrm{SiCl}\right)_{2}$ were dissolved in $9 \mathrm{~mL}$ of tetrahydrofuran (THF) with a molar ratio of $\mathrm{H}_{3} \mathrm{PO}_{4}:\left(\mathrm{C}_{2} \mathrm{H}_{4}\right)\left(\mathrm{Me}_{2} \mathrm{SiCl}\right)_{2}=1: 1.5$ with stirring and then gradually heated to 50,100 , and $150^{\circ} \mathrm{C}$ in $30 \mathrm{~min}$. Then, the solutions were kept at each temperature for $5.5 \mathrm{~h}$ and cooled to ambient temperature. The $\mathrm{H}_{3} \mathrm{PO}_{4}-\left(\mathrm{C}_{6} \mathrm{H}_{4}\right)\left(\mathrm{Me}_{2} \mathrm{SiCl}\right)_{2}$ system was conducted by the same procedure as the $\mathrm{H}_{3} \mathrm{PO}_{4}-\left(\mathrm{C}_{2} \mathrm{H}_{4}\right)\left(\mathrm{Me}_{2} \mathrm{SiCl}\right)_{2}$ system. The compositions of the precursors in this system were changed as $\mathrm{H}_{3} \mathrm{PO}_{4}:\left(\mathrm{C}_{6} \mathrm{H}_{4}\right)\left(\mathrm{Me}_{2} \mathrm{SiCl}\right)_{2}=1: \mathrm{x}(\mathrm{x}=0.5,1.0,1.5,1.68,2.0,2.5,3.0)$.

The ${ }^{31} \mathrm{P}$ NMR and ${ }^{29} \mathrm{Si}$ NMR spectra were measured using Varian Unity-Inova (300 MHz) and JEOL ECX400, ECS400. The samples for NMR measurements were prepared by 3-fold diluting the resulting viscous liquid with chloroform-d (98.00\%, Wako Pure Chemical Industries, Ltd., Tokyo, Japan) and THF (super dehydrated with stabilizer, $\geq 99.5 \%$, Wako Pure Chemical Industries, Ltd.). The chemical shift of ${ }^{31} \mathrm{P}$ was obtained relative to that of $85 \% \mathrm{H}_{3} \mathrm{PO}_{4}$. The chemical shift of ${ }^{29} \mathrm{Si} \mathrm{NMR}$ was obtained relative to that of tetramethyl silane.

The molecular weights of the samples were estimated by a GPC with Tosoh CO-8020, RI-8020, DP-8020, and SD-8022 systems (Tosoh Co., Tokyo, Japan) equipped with a guard column (Tosoh TSKgel guard column SuperHZ-L, Tosoh Co., Tokyo, Japan) and three analytical columns (two Tosoh TSKgel SuperHZ1000 columns, and a TSKgel SuperHZ2000 column (Tosoh Co., Tokyo, Japan)) at $40{ }^{\circ} \mathrm{C}$. Polystyrene standards (TSKgel Standard Polystyrene, Tosoh Co., Tokyo, Japan) were employed for the calibration. Tetrahydrofuran (THF)was used as the eluent at a flow rate of $1.0 \mathrm{~mL} / \mathrm{min}$. 
The DFT calculations at the B3LYP/6-31+G(d,p) level were carried out for the $\mathrm{H}_{2} \mathrm{PO}_{4}^{-}$, $\left(\mathrm{C}_{2} \mathrm{H}_{4}\right)\left(\mathrm{Me}_{2} \mathrm{SiCl}\right)_{2}$, and $\left(\mathrm{C}_{6} \mathrm{H}_{4}\right)\left(\mathrm{Me}_{2} \mathrm{SiCl}\right)_{2}$ using the Gaussian 09 program [28]. The DFT calculations were also performed for the cage-type $(\mathrm{PO})_{2}\left(\mathrm{Ph}\left(\mathrm{Me}_{2} \mathrm{SiO}\right)_{2}\right)_{3}$ molecules to determine the stabilized molecular structure.

\section{Conclusions}

Silicophosphate oligomers with alternating hybrid copolymer structures were prepared from phosphoric acid and organo-bridged bis(chlorosilane) $\left(\left(\mathrm{C}_{2} \mathrm{H}_{4}\right)\left(\mathrm{Me}_{2} \mathrm{SiCl}\right)_{2}\right.$ or $\left.\left(\mathrm{C}_{6} \mathrm{H}_{4}\right)\left(\mathrm{Me}_{2} \mathrm{SiCl}\right)_{2}\right)$ by nonaqueous acid-base reactions. In the $\mathrm{H}_{3} \mathrm{PO}_{4}-\left(\mathrm{C}_{2} \mathrm{H}_{4}\right)\left(\mathrm{Me}_{2} \mathrm{SiCl}\right)_{2}$ system with a stoichiometric composition, $\mathrm{P}-\mathrm{OH}$ or $\mathrm{Si}-\mathrm{Cl}$ terminated linear and/or cyclic oligomers were mainly prepared at $50{ }^{\circ} \mathrm{C}$ and $\mathrm{P}-\mathrm{OH}$ terminated cyclic oligomers and polyhedral (e.g., cage and double-decker) oligomers were likely obtained at 100 and $150{ }^{\circ} \mathrm{C}$. In the $\mathrm{H}_{3} \mathrm{PO}_{4}-\left(\mathrm{C}_{6} \mathrm{H}_{4}\right)\left(\mathrm{Me}_{2} \mathrm{SiCl}\right)_{2}$ system, at the stoichiometric composition, $\mathrm{P}-\mathrm{OH}$ or $\mathrm{Si}-\mathrm{Cl}$ terminated oligomers were obtained at temperature below $100{ }^{\circ} \mathrm{C}$. Importantly, low molecular weight ring and cage oligomers (ring tetramer, cage pentamer, and ring hexamer) were considered to be synthesized in the product prepared at $150{ }^{\circ} \mathrm{C}$. At the $150{ }^{\circ} \mathrm{C}$ reaction temperature, an excess of phosphoric acid $(x=0.5$ and 1.0) led to a self-condensation of phosphoric acid that impeded the formation of P-O-Si linkages, while the excess of $\left(\mathrm{C}_{6} \mathrm{H}_{4}\right)\left(\mathrm{Me}_{2} \mathrm{SiCl}\right)_{2}$ resulted in the $\mathrm{Si}-\mathrm{Cl}$ terminated products with a wide range of molecular weight where almost all phosphorous had three P-O-Si linkages with $\left(\mathrm{C}_{6} \mathrm{H}_{4}\right)\left(\mathrm{Me}_{2} \mathrm{SiCl}\right)_{2}$ molecules.

The present synthetic approach for the alternating hybrid copolymers opens the simple and facile way to prepare small rings or cages that are expected for applications in gas sorption, drug delivery, and others as micro structure building units with a small cavity within them.

Supplementary Materials: The following are available online at http:/www.mdpi.com/1420-3049/25/1/127/s1, Figure S1: The ${ }^{1} \mathrm{P}$ and ${ }^{29} \mathrm{Si}$ NMR spectra and GPC data of the product prepared from phosphoric acid and $\left(\mathrm{C}_{2} \mathrm{H}_{4}\right)\left(\mathrm{Me}_{2} \mathrm{SiCl}\right)_{2}$ at $150{ }^{\circ} \mathrm{C}$. Figure S2: the ${ }^{29} \mathrm{Si}$ NMR spectra of the products prepared from phosphoric acid and $\left(\mathrm{C}_{6} \mathrm{H}_{4}\right)\left(\mathrm{Me}_{2} \mathrm{SiCl}\right)_{2}$ at $\mathrm{x}=1.5$ and 3.0. Figure S3: GPC data for the product prepared at $\mathrm{x}=1.5$ and 3.0. Figure S4: the ${ }^{1} \mathrm{P}$ NMR spectrum and GPC data for the product prepared from phosphoric acid and $\mathrm{Me}_{2} \mathrm{PhSiCl}$ at $100{ }^{\circ} \mathrm{C}$. Figure S5: Possible molecular structures of a cage oligomer made from two phosphoric acid and three $\left(\mathrm{C}_{6} \mathrm{H}_{4}\right)\left(\mathrm{Me}_{2} \mathrm{SiCl}\right)_{2}$ molecules. Figure S6: Schematic illustration of the stabilized molecular structure of cage oligomer.

Author Contributions: Writing, original draft preparation, K.O.; investigation, M.T. (Masanari Takano); formal analysis, Y.T. (Yasuaki Tokudome); DFT calculation, Y.T. (Yomei Tokuda); conceptualization M.T. (Masahide Takahashi); writing, review and editing, M.T. (Masahide Takahashi). All authors have read and agreed to the published version of the manuscript.

Funding: This work was partly supported by a Grant-in-Aid for Scientific Research (KAKENHI) from the Ministry of Education, Culture, Sports, Science, and Technology of Japan.

Acknowledgments: In this research work we used the supercomputer of ACCMS, Kyoto University.

Conflicts of Interest: The authors declare no conflict of interest.

\section{References}

1. Schubert, U.; Huesing, N.; Lorenz, A. Hybrid Inorganic-Organic Materials by Sol-Gel Processing of Organofunctional Metal Alkoxides. Chem. Mater. 1995, 7, 2010. [CrossRef]

2. Loy, D.A.; Shea, K.J. Bridged Polysilsesquioxanes. Highly Porous Hybrid Organic-Inorganic Materials. Chem. Rev. 1995, 95, 1431. [CrossRef]

3. Wen, J.; Wilkes, G.L. Organic/Inorganic Hybrid Network Materials by the Sol-Gel Approach. Chem. Mater. 1996, 8, 1667. [CrossRef]

4. Schottner, G. Hybrid Sol-Gel-Derived Polymers: Applications of Multifunctional Materials. Chem. Mater. 2001, 13, 3422. [CrossRef]

5. Mutin, R.H.; Guerrero, G.; Vioux, A. Hybrid materials from organophosphorus coupling molecules. J. Mater. Chem. 2005, 15, 3761. [CrossRef] 
6. Buestrich, R.; Kahlenberg, F.; Popall, M.; Dannberg, P.; Müller-Fiedler, R.; Rösch, O. ORMOCER ${ }^{\circledR}$ s for optical interconnection technology. J. Sol-Gel Sci. Technol. 2001, 20, 181. [CrossRef]

7. Luo, X.; Zha, C.; Luther-Davies, B. Preparation and optical properties of titania-doped hybrid polymer via anhydrous sol-gel process. J. Non-Cryst. Solids 2005, 351, 29. [CrossRef]

8. Vioux, A. Nonhydrolytic sol-gel routes to oxides. Chem. Mater. 1997, 9, 2292. [CrossRef]

9. Niida, H.; Takahashi, M.; Uchino, T.; Yoko, T. Preparation and structure of organic-inorganic hybrid precursors for new type low-melting glasses. J. Non-Cryst. Solids 2002, 306, 292. [CrossRef]

10. Niida, H.; Takahashi, M.; Uchino, T.; Yoko, T. Structure of organic-inorganic hybrid low-melting glasses from ${ }^{29} \mathrm{Si}$ NMR and ab initio molecular orbital calculations. J. Non-Cryst. Solids 2002, 311, 145. [CrossRef]

11. Niida, H.; Takahashi, M.; Uchino, T.; Yoko, T. Preparation of organic-inorganic hybrid precursors $\mathrm{O}=$ $\mathrm{P}\left(\mathrm{OSiMe}_{3}\right)_{x}(\mathrm{OH})_{3-x}$ for low-melting glasses. J. Ceram. Soc. Jpn. 2003, 111, 171. [CrossRef]

12. Mizuno, M.; Takahashi, M.; Tokuda, Y.; Yoko, T. Substituent effect on the formation of organically-modified silicate-phosphate alternating copolymer through nonaqueous acid-base reaction. J. Sol-Gel Sci. Technol. 2007, 44, 47. [CrossRef]

13. Takahashi, M.; Niida, H.; Tokuda, Y.; Yoko, T. Organic-inorganic hybrid phosphite low-melting glasses for photonic applications. J. Non-Cryst. Solids 2003, 326, 524-528. [CrossRef]

14. Mizuno, M.; Takahashi, M.; Uchino, T.; Yoko, T. Organic-inorganic hybrid material of phenyl-modified polysilicophosphate prepared through nonaqueous acid-base reaction. Chem. Mater. 2006, 18, 2075. [CrossRef]

15. Mizuno, M.; Takahashi, M.; Yoko, T. Structure and water durability of tin(II) organosilicophosphate glasses prepared by nonaqueous acid-base reactions. J. Mater. Res. 2006, 21, 1798. [CrossRef]

16. Kakiuchida, H.; Takahashi, M.; Tokuda, Y.; Yoko, T. Rewritable holographic structures formed in organic-inorganic hybrid materials by photothermal processing. Adv. Funct. Mater. 2008, 19, 2569. [CrossRef]

17. Inagaki, S.; Guan, S.; Ohsuna, T.; Terasak, O. An ordered mesoporous organosilica hybrid material with a crystal-like wall structure. Nature 2002, 416, 304. [CrossRef]

18. Reuter, K.; Maas, R.G.M.; Reuter, A.; Kilgenstein, F.; Asfaha, Y.; Hänisch, C. Synthesis of heteroatomic bridged paracyclophanes. Dalton Trans. 2017, 46, 4530. [CrossRef]

19. Wang, S.; Wang, J.; Cheng, W.; Yang, X.; Zhang, Z.; Xu, Y.; Liu, H.; Wu, Y.; Fang, M. A Zr metal-organic framework based on tetrakis (4-carboxyphenyl) silane and factors affecting the hydrothermal stability of Zr-MOFs. Dalton Trans. 2015, 44, 8049. [CrossRef]

20. Furukawa, H.; Ko, N.; Go, Y.-B.; Aratani, N.; Choi, S.B.; Choi, E.; Yazaydin, A.Ö.; Snurr, R.Q.; O’Keeffe, M.; Kim, J.; et al. Ultrahigh porosity in metal-organic frameworks. Science 2010, 329, 424. [CrossRef]

21. Sánchez, A.C.; Craig, G.A.; Larpent, P.; Guillerm, V.; Urayama, K.; Maspoch, D.; Furukawa, S. A Coordinative Solubilizer Method to Fabricate Soft Porous Materials from Insoluble Metal-Organic Polyhedra. Angew. Chem. Int. Ed. 2019, 58, 6347. [CrossRef] [PubMed]

22. Vaugeois, Y.; De Jaeger, R.; Levalois-Mitjaville, J.; Mazzah, A.; Wörle, M.; Grützmacher, H. Synthesis and Structure of New Eight-Membered Si-O- $\lambda^{5} \sigma^{4}$-P Heterocycles. New J. Chem. 1998, 22, 783. [CrossRef]

23. Murugavel, R.; Prabusankar, G.; Walawalkar, M.G. Organic Soluble Silicophosphonate $\left[\mathrm{RSi}(\mathrm{OH})\{\mathrm{OP}(\mathrm{O})(\mathrm{H})(\mathrm{OH})]_{2} \mathrm{O}\left(\mathrm{R}=\left(2,6-i-\mathrm{Pr}_{2} \mathrm{C}_{6} \mathrm{H}_{3}\right)_{\mathrm{N}} \mathrm{SiMe}_{3}\right)\right.$ : The First Silicophosphonate Containing Free $\mathrm{Si}-\mathrm{OH}$ and $\mathrm{P}-\mathrm{OH}$ Groups. Inorg. Chem. 2001, 40, 1084. [CrossRef] [PubMed]

24. Jähnigen, S.; Brendler, E.; Böhme, U.; Kroke, E. Synthesis of Silicophosphates Containing $\mathrm{SiO}_{6}-\mathrm{Octahedra}$ under Ambient Conditions-Reactions of Anhydrous $\mathrm{H}_{3} \mathrm{PO}_{4}$ with Alkoxysilanes. Chem. Commun. 2012, 48, 7675. [CrossRef]

25. Jähnigen, S.; Böhme, U.; Kroke, E. Silicophosphates containing $\mathrm{SiO}_{6}$ octahedra-Anhydrous synthesis under ambient conditions. New J. Chem. 2014, 38, 744. [CrossRef]

26. Styskalik, A.; Babiak, M.; Machac, P.; Relichova, B.; Pinkas, J. New adamantane-like silicophosphate cage and its reactivity towards tris(pentafluorophenyl)borane. Inorg. Chem. 2017, 56, 10699. [CrossRef] 
27. Styskalik, A.; Skoda, D.; Moravec, Z.; Babiak, M.; Barnes, C.E.; Pinkas, J. Control of Micro/mesoporosity in Non-Hydrolytic Hybrid Silicophosphate Xerogels. J. Mater. Chem. A 2015, 3, 7477. [CrossRef]

28. Frisch, M.J.; Trucks, G.W.; Schlegel, H.B.; Scuseria, G.E.; Robb, M.A.; Cheeseman, J.R.; Zakrzewski, V.G.; Montgomery, J.A.; Stratmann, R.E., Jr.; Burant, J.C.; et al. Gaussian 98, Revision A.11; Gaussian, Inc.: Pittsburgh, PA, USA, 2001.

Sample Availability: Samples of the compounds are not available from the authors.

(C) 2019 by the authors. Licensee MDPI, Basel, Switzerland. This article is an open access article distributed under the terms and conditions of the Creative Commons Attribution (CC BY) license (http://creativecommons.org/licenses/by/4.0/). 